\title{
Culture, Language and Evolution of African Literature
}

\author{
${ }^{1}$ Dr George Anaso (Phd), ${ }^{2}$ Nwabudike, Christopher Eziafa \\ Department of English, Federal University Dutsin-Ma, Katsina State Nigeria.
}

\begin{abstract}
This paper: culture, Language and Evolution of African Literature has its main thrust in explaining what Literature as a field of study is all about, together with its usefulness to mankind. This usefulness has to do with empowering the reader language- wise and imparting to him a civilizing value, thus making him a better person to function in human environment socially morally and intellectually. This is against the backdrop of racial denigration of African Literature by imperialist critics who deny it having universalism in terms of concept. This is in the spirit of Western Eurocentricism which regards every idea that does not originate from them as not having universalism in content. This paper condemns this unwholesome attitude of the Western Europe using the views of African writers and argues that universalism can emanate from anywhere in the globe. The paper also indicates that only an open - minded approach to Literature from all parts of the world can reveal ideas with universal applicability, not only works from Western Europe. Secondly, Literature is seen as a potent tool for enriching human experience and fostering universal truths. Also, Literature can be appreciated for the intrinsic aesthetic values of their places of origination. This paper postulates in summation that Literature in a potent means of enhancing universal understanding and cultural globalization both now and in the future, and mankind will be better off with it. In conclusion, the paper submits that only an open-minded approach to Literature involving a willingness to accept the truths in the literary works being considered (even if such truths run counter to one's preconceived ideas), a character nurtured by the study of Literature, will enrich mankind intellectually and morally.
\end{abstract}

Keywords: Cultural, evolution, globalization, universalism, aesthetic, denigration.

\section{Introduction}

Literary Art scholars may want to interrogate the necessity of beginning this paper with a definition of the term: Literature. For one thing, there are almost as many definitions of literature as there are writers. Another thing is that assumedly, everyone in the literary studies knows what Literature is and can attempt a functional definition of the term. However, for a common understanding and, to give us a working definition, we shall adopt the definition of Literature as: "written material such as poetry, novels, short stories, essays etc, especially works of imagination characterized by excellence of styles and expression and by general or enduring interest (Soile, 1998). Our adoption of this definition is based on its versatility to accommodate most shades of opinion about the term.

Literature can, however be seen as the use or manipulation of language tool in the best form for the purpose of exploring human experience in diverse situations. The empirical study of any language by this means cannot be accomplished except its Literature component is explored vis a vis. Literature is usually the creative works of the best brains in a particular language and culture.

The usefulness of Literature as can be seen in the light of the foregoing has first to do with the study of a language as a medium of communication which brings us into contact with our world. This is necessary for both our physical and spiritual well - being because language touches on both.

Secondly, Literature has a civilizing value, opening before us a vista into the universal human experience as opposed as potion or assertion by scholars with non - literary background, who conceive Literature as mere story - telling medium.

Thirdly, Literature can create a better citizen because of its salutary influence on our psyche and attitude to life. This is greatly in a way that it can train our minds to receive opposing values. It is basically on this platform that Literature has become a veritable element for cultural globalization, especially for Africa whose Literature has been denigrated and repudiated by Western critics all along, on the claim that African Literature does not aspire to ideological universalism; which they claim to be peculiar reserve of the Western works, to the exclusion of works from other races. After all, western literary works, like the African, emerged from the pre - literate western cultures to what they later on become in the Middle - age.

Key pillars in the Study and Inscription of Literary Works

Literary works are rooted in three basic pillars:

(a) the background of the author 
(b) the historical antecedents of the setting and / or plot, and

(c) the creative spirit under whose influence or inspiration the writer is working at a particular time (ie the genius).

Looking at the above elements briefly, the background of the writer includes the writer's cultural orientation, his training or education and his peculiar nature, character or attitude to life. The historical antecedents of the setting or plot of the work dictates the source of his story and his choice of a particular anecdote or story vis a vis his purpose for writing the work. Finally, the creative spirit is the muse (or genius story) that controls or inspires his psyche at the time of creativity. For example, in the play "King Lear", Shakespeare appears to establish a link between man and the genius because man (the artist) is not always in his conscious mind during creativity. The genius takes over the creative process or the psyche of the creator to highlight things he would not ordinarily see in his normal life.

Artists in general are quite aware of the intrusion of the genius (the creative spirit) in any creative work. The work of creativity is akin to the creative work of the universe done by the Almighty God. By engaging in the work of creativity, mankind is partaking in and complementing this creative activity, thus contributing to enrich the earth in his own way, thereby sharing in that divine creative characteristic, after all, we are gods in our own right. (see Psalm 82 v 6, Isaiah 41 v 23, John 10 v 34). During artistic creation, man appears to fall into an illusion which takes control of his psyche and consciousness. This illusion is caused by the genius so as to enhance the creative capability and vision. Hence, it is said that at creative moments, the artist has something in common with the lover and the lunatic who are under illusion. An awareness of this creative process is necessary to appreciate value in a work of artistic creativity.

\section{Literature And Linguistic Evolution}

It is a known fact that Literature impacts on linguistic development. Chinua Achebe's transliteration of local Igbo expressions into English in a way that is peculiar, for instance, has taught the literary world a new linguistic phenomenon which soon became popular among and inspired Africa writers. This linguistic emergence issued from Achebe's realization that no foreign language can be used to clearly express or capture the thoughts of another society whose mothertongue is different. Achebe's successful transliteration in his novels enables readers to understand the thoughts expressed as they are rendered originally and also carries the reader along; despite the fact that arch - linguists and conservative Western Imperialist critics saw Achebe's work as an attempt to corrupt the "well established English language that had for many centuries impeccably fostered and provided leverage and direction to human thoughts and expression, as well as the moral and intellectual development“. (Woakes, 1981:37).

Wole Soyinka has also explored the technique of more or less; translation when he translated D. O. Fagunwa's The Forest of a Thousand Demons from Yoruba language (the original Language of the book) to English. Soyinka's intension was to enable non - Yoruba speakers enjoy the art of Fagunwa. In a general sense, the technique of translation (and in fact, transliteration) has provided a good leverage to African Literature to be read and African thoughts appreciated by all readers across the globe because some of these works have been translated into several foreign languages of the world. From this perspective, we need to recall that Chinua Achebe, who writes mostly African themes, has exported African culture to all nooks and corners of the earth where it is now read about with better understanding and interest.

\section{Literature as a Vehicle for Cultural Dispersal}

Until recently the history, only the Western Literatures were recognized and studied for academic, moral, and intellectual upliftment; while African Literature which was fairly new had not been seen as a field for any serious contemplation and scholarship. The impact of Western imperialism was such that European history and literature were very strong forces used in cementing imperialism in the minds of the colonized nations, to the denigration of their history and Literature. This denigration was rooted in the Western universalist conceit which regarded as superior every thought and idea from the West over those from all other races of the earth. To these universalists, only the Western Literatures were accepted as possessing universality in terms of truths, human experiences and intellectual depth.

African Literature which was viewed as emanation from the underdeveloped world was therefore considered as unworthy of any attention. There were even arguments in some quarters as to whether Africa had literature or orature, since the bulk of what was seen as African Literature had its root in oral tradition; and that no preliterary society should be considered as having literature.

Western universalistic concept was well captured by both Said in The Wretched of-the Earth (1961) and Fanon in Orientalism (1971) as parts of their literary contributions to the decolonization of Africa. These books provided a rigorous method of analyzing the phenomenon of conquest, domination and resistance in previously colonized societies; thereby enhancing the decolonization process of both the African psyche and literature. 
However when a new educated breed of writers emerged in Africa; the imperialist literary trend started weakening down as a result of anti-colonialist writings in African Literature, exposing the imperialist fallacies about Africa and her people's cultures.

Dr Kwame Nkrumah's spontaneous reaction was one of such attempts at exposing the imperialist intentions of the Western powers He said:

The history of Africa as presented by European scholars had been encumbered with malicious myths. It was even denied that we were a historical people... Such disparaging account had been given of Africa societies and their culture as to justify slavery; and slavery posed against these accounts served as positive deliverance of our ancestors. (Kwame Nkrumah, 1957:18)

Europe used the fallacious accounts given by their explorers and early sojourners in Africa as bases to justify slavery and, thereafter, colonialism, with all the evil trails of dehumanization and truncation of many nations to satisfy the imperial interests of these European powers. How else could they defend colonialism and slavery if they acceded to African humanity?

As a reaction against this imperialist world and its attitude to the African, Achebe wrote Things Fall Apart in 1958 and explained the purpose for his work as follows;

... a purpose implicit or expressed, to correct the distortion of West Africa cultures, to recreate the past in the present in order to educate the West African reader and give him the confidence in his cultural heritage which had been eroded by colonialism, and also in order to enlighten the foreign reader and help him get rid of the false impressions about the West African cultures acquired from centuries of cultural misrepresentation. (Obiechina, 1972:244)

Achebe's attempt at re-educating his audience is through Literature which can be seen clearly as a potent tool to correct all the racial misrepresentations intended to establish the assumed cultural superiority of one race over the others as exposed in the concept of Western universalism. As for the allegation that West African people had no culture before the advent of the white men, that what the West Africans have today was as a result of Western influence; Achebe, through his early works - Things Fall Apart and Arrow of God points out clearly that West African people did not hear of culture first from the white people; that the people had well established cultural and social organizations which the Europeans met on the ground on their arrival. This kind of cultural and historical orientation of the readers has been accomplished by the means of Literature.

Also, an effort was made by Sol.T. Plaatje to debunk the imperialist falsification of the traditional life of the Barolong of South Africa. In the introduction to Mudhi. Couzzens explained as follows;

The concern of Plaatje is and only to defend the custom and the traditional life of the Barolong, and to some extent, he is also intent on re-interpreting history from the point of view of his own people. (Mudhi; 1930:10)

The above portrays a genuine need to use Literature to correct racial misrepresentation through presenting the other side of the coin dialectically, not necessarily by polemics.

Oke (1972) in justifying the role of Literature in exploring universal truths about mankind explained that:
...Literature is the total expression of the universal man and eternal
truths, not just a chronicle of a civilization.

Furthermore, Achebe sees Literature as incorporating story-telling, from the perspective of functionality. He emphasizes the use of story-telling for educational purposes when he declares that:

... it is only the story that can continue after the war and the warrior. It is the story that outlives the sound of war drums and exploits of brave fighters. It is the story, not the others that saves our progeny from blundering like blind beggars into the spikes of the cactus fence ...the story is our escort; without it, we are blind ... (Anthills of Savanna, 124)

At the wake of independence struggles, in the early nineteen, African writers were in the frontline of libration efforts. Apart from the earlier works of Gustavuus Vassah (Equiano's Travels) and Sol .T. Plaatje (Mudhi) other anti-colonial writings flowered, especially in West Africa to add fervour to the decolonization efforts. The French-speaking West African writers became more vibrant in this struggle than their English speaking counterparts, perhaps owing to the "assimilation policy" of France in their African colonies. However, the struggle against imperialism led to the formation of the Negritude movement which was characterized by the following features:

- A rejection of white culture;

- A fresh and sympathetic look at the African culture;

- A cultural unity of all the black people;

- Link with the mother Africa; and

- Assertion of the African humanity. (Soile 1998:16)

The adoption of these features as an article of faith among African writers was later to culminate in the formation of the Black and Africa Festival of Art and Culture which brought all the black people together - first 
in the Congo Democratic Republic, and then in Lagos, Nigeria in 1977. This FESTAC as it became known, not only fostered unity among the blacks, but also lent solidarity and esprit de corps to South African people still grappling with the Apartheid government. Furthermore, blacks in diasporas' started looking inside Africa to discover and reestablish contact with their roots. These activities added potency to African unity.

Considering the above literary exploits of African writers and their effectiveness in dismantling imperialism in Africa, it is clear that Literature has been a potent tool in cultural liberation and globalization across the world. It is in tune with the role that Literature can play in opening up better literary and cultural understanding that Achebe feels that the cultural richness of mankind distributed by nature can be realized when he avers:

Let every people bring their gift to the great Festival of the world's cultural harvest and mankind will be the richer for the variety and distinctiveness of the offering.... (Achebe, 1979:18)

Literary works should be considered with great openness of the heart whereby one would be able to reasonably appreciate the values of works from other societies and the truths encapsulated in and emanating from such works, even if such do not conform to one's own ideas. In this way, universalism will begin to be seen to emerge from such literary works, because it is not, and can never be peculiar to only a particular racial group in the world, as euro-centricism tended to emphasise.

\section{Literature And Negativism}

Negativism can be seen or located in the context of negative feelings or perceptions against normal human nature and cultural heritage of people different from one's peculiar group or race. History has been manipulated in some cases to promote this negative tendency used to oppress other human groups to score the cheap political point of showing the false cultural superiority of one race over another. All about colonial and post colonial literature is that, they deal with Europe painting a poorly conceived picture of Africa to justify European slavery of African, and African writing (and writers) trying to tell their own story or version of the European tales. African writers who sing a different tune from the Europeans are made objects of European colonialist criticism. The African work that has attracted the most vicious colonialist attacks is Things Fall Apart whose genuine intention of Achebe is, as stated earlier is to present Africa's own side of the story. Literature demands a patient study and understanding of the African situation and culture before the advent of the white people. It was not a long night of barbarism and listless mindlessness as portrayed by the Western European. Those who claim to be the originators of Literature have all the while manifested much of inane ignorance of what Literature is intended to achieve in human life. They are rather led by the historical fallacies peddled in Europe the pre-colonial and colonial era, blinded by colonialist intensions. Up to the present (contemporary) era, the West has demonstrated the saying that 'old habits die hard' by still manifesting the bias against African anticolonialist works. How else could their denial of the merited Nobel prize for Literature to Chinua Achebe when it was the turn of Africa? Achebe, who is among the ten most researched writers in the world, Achebe whose one singular novel - Thing Fall Apart has been translated into more than sixty languages in the world, Achebe who edited about two hundred African novels under the African Writers Series (AWS) - apart from all his other novels, poetry, short stories, letters and Essays etc, and who is generally acclaimed as the literary icon as well as the "Father" of African Literature - was denied the Nobel prize because his works attacked colonialism in African. This is the height of calculated negativism, cultivated, natured and harvested by the anti - literary, spiritually warped impostors who though claim to be the makers of civilization, yet fail to back up their claim reasonably with convincing proofs and corresponding civilization. In one ignorance of what literature is intended to achieve in human life.

\section{Summary And Conclusion}

The above discussion shows that Literature has an immense value and can play a very significant and formidable role in scholarship and further intellectual development of the entire world. Apart from being a tool for Linguistic development, it is also an asset in building mankind up morally and in erecting intellectual bridges, thus making mankind wiser and better citizens of the world. This is in view of the world now turning into a global village where all people are expected to begin to exhibit singular willingness to see things from a general perspective as members of one large human community, rather than from individual narrow points of view. It is from this perspective of Literature that the world could become a better place for mankind to live in and be able to function safely and freely, generate and galvanize knowledge peace and understanding, and enhance better human relations on the global scale. From this perspective, one cannot but accept the fact that the full potential of literature has not been explored in the human community. Nevertheless, only open-minded study of world literatures can allow the subject release fully the potential benefits it holds in stock for mankind in terms of both aesthetics and universal truths being locked up behind the iron bars of narrow-mindedness and conceited approach to their studies. In this way also, Literature and Language development can be clearly seen 
to emerge from cultural representation which transmits universally acceptable moral truth and this is what is seen as universalism.

\section{References}

[1]. Achebe, C. (1985) Anthills of Savanna (AWS) London: Heinemann.

[2]. (1958) Things Fall Apart (AWS) London Heinemann.

[3]. Anaso, G. N. (2006) "Literature as Social Discourse: a Case Study of the Social and ideological Dimensions of Conflict in the Selected Novels of Chinua Achebe and Timothy M. Aluko", an unpublished PhD Dissertation presented to the Department of English and Literary Studies, Ahmadu Bello University, Zaria.

[4]. Couzzens (1975) 'introduction' to Mudhi Johannes bury:? Quagga press.

[5]. Fanon, F. (1961) The Wretched of the Earth, New York: Penguin.

[6]. Nkrumah, Kwame (1957) Conscience, Accra: Government Press.

[7]. Obiechina, E. (1975) Culture, Tradition and Society in the West African Novel, Cambridge: C. U. P

[8]. Oke, D. O. (1972) 'Some Thoughts on the Functions of Literary Criticism in Nigeria Education' Journal of the Nigeria English Studies Association Vol.5, Nos 1 and 2.

[9]. Said, W. F. (1971) Orientation, Western Conception of Others, London: Routledge.

[10]. Shakespeare, W. (Rep. 1980) King Lear (New Swan edn.)

[11]. Woakes, L. S. (1981) English Language, Practice and Phantasy, London: Pantheon Press. 